\title{
I am Ngaitai - Ko Ahau te Uri: A discovery of Indigeneity
}

\begin{abstract}
The terms Indigenous and indigeneity are used to position groups of people who are classed with the same ideology. What is indigeneity and what is not indigeneity? What are the boundaries needed to belong and to utilise this framework? Do we as Māori or do I as a Ngaitai Women need to align and belong to an indigenous world for the pure intent to validate my own identity? Where does Te Tiriti o Waitangi fit in this space and how do I align my practice?

I am Ngaitai - Ko Ahau te Uri is a positioning perspective on the notion of indigeneity and also looks at the roller coaster ride through whakapapa and social work practice when utilising terms that have a political agenda.
\end{abstract}

\section{Introduction}

The use of the words Indigenous and indigeneity are relatively new in my list of English vocabulary. The term Indigenous is and has been used worldwide since the beginning of the 1980s however it can be debated that this was used around the 1970's steering away from the terms used to describe native and original peoples of a particular land. In short, the use of the term ethnic and original inhabitants in a region was used to describe groups that had settled in a specific region.

The word indigenous is also rooted in the Latin word indigenous "born in a country, native," but is also a word that includes birth, born into or born into a place. Confused? Words such as aboriginal, native and first nations are used and have evolved; however, a question would be was there ever a need to rename a people group in the collective? Moreover, hasn't this just complicated and recolonised those who originated in a land? Has this been a way to redefine 
and label groups of people ensuring that governments have the ease of pursuing their own identity?

In this paper, the use of the terms indigenous and indigeneity are open for discussion more over what is my position in my practice in the utilisation of such terms within Te Ao Māori (The Māori World)?

Audra Simpson (2007) explains that "to speak of Indigeneity is to speak of colonialism and anthropology" is the use of the terminology a way of power and control over those that originated in a land? Is it a form of a hegemonic power or practice by those that govern countries or those that hold the dominant space in a political world? (Simpson, 2007, p.67)

There is also another challenge I face when exploring where my practice sits which is a little closer to home in the space of Te Ao Māori. That is the discovery of new knowledge. Charles Royals (2007) "The Creative Potential Paradigm looks at the various transitions through aspects of new creative potential paradigms through the Māori world but also looks at overcoming past experiences to be inspired for new thinking to be born. Durie (2005) also makes a note of this explaining that "Royal has described a research paradigm, Te Ao Marama that employs a whakapapa methodology to develop new knowledge."

Could the Creative Potential paradigm that Royal explains challenge my view on indigenous methods? Is it a way to change the way Māori are perceived in their respective professions while remaining distinctive? Is the transition from Te Ao Māori to Te Ao Marama similar to that of a transitional move to indigenous ways of thinking in a broader context of social work practice?

This paper I am Ngaitai - Ko Ahau te Uri, will look at where I position my practice in today's society and the workspace of Social Work in Aotearoa. Is there a distinction between Iwi and indigeneity? Are the terms indigenous and indigeneity needed to validate a position? Moreover, in what space is it appropriate when I believe there are answers and solutions in the different paradigms of Te Ao Māori? 


\section{A roller coaster ride of the universal kind: The Political realm of the terms indigenous and indigeneity}

In 2007 the United Nations Declaration on the Rights of Indigenous Peoples was adopted by a majority of 144 states in favour of: 4 voted no, which included New Zealand; 11 states abstentions and non-voting were 34 . Fast forward ten years and the four countries that voted no have repositioned themselves and now support the United Nations Rights of Indigenous Peoples. On a large scale, the position of the United Nations declaration is an international framework for the survival, well-being, dignity which elaborates on the existing human rights and freedoms as they apply to indigenous peoples. (United Nations, 2018)

Sound daunting? Merlan (2009) explains "there has been acceptances, rejections and strategic uses of the concept of indigeneity" and that "concepts drawn from internationalist indigeneity are used strategically in a range of contexts". She goes on to explain that "The principal institutional home of international indigenism is within the United Nations system", including states that claim indigenous and indigeneity does not apply to them. (p. 303)

Merlan (2009) also states that some "critics of the novote saw this as a serious tactical error making the four states stand out as colonial, white and anachronistic in a world where de-colonisation was taking place". Such a strong statement where there is now history in a political realm on the human rights of indigenous peoples.

Guenther (2006) also presents an argument and critique from Alan Barnard with Kuper's rejection of the "indigenous peoples" were arguing for indigenous is to allow for its validity and to be used as a tool for political use. As Guenther (2006) states Barnards views are of the recognition of indigenous peoples. Kuper argues that "The notion of 'indigenous people's "is an ideological makeover of the old idea of 'primitive people'". (Barnard, 2006; Kuper, 2006 as cited in Guenther, 2006, p17) Kuper's argument brings back a broader debate, and that is of the words used to describe or label things, in this instant the description of people. As I mentioned, the word is rooted in the Latin, quite a far cry away from Aotearoa, New Zealand and perhaps our unique descriptions of things. 
This could also start to get confusing because in Aotearoa we have The Treaty of Waitangi with four articles that affirm the rights that Tangata Whenua had before 1840, but it also gave the crown rights and responsibilities enabling them to settle in Aotearoa. There are 46 articles in the United Nations declaration of indigenous rights; 37 articles that explain the rights, five articles that explain how the declaration is to be applied and four that set out the rights of the declaration.

With Aotearoa agreeing to the declaration in 2010 it quickly aligned the unique identity of The Treaty of Waitangi and The Declaration which assisted in the interpretation and the application of the treaty principles. The Minister of Justice (2010) stated: "In keeping with our strong commitment to human rights and indigenous rights, in particular, New Zealand now adds its support to the declaration both as an affirmation of fundamental rights and in its expression of new and widely supported aspirations." (Ministry Statements and Speeches 2010.)

With the declaration in full swing here in Aotearoa, it could cause some concern for those who do not agree with the stance Aotearoa has taken let alone for those who do not align their daily practice with the declaration or the terms indigenous and indigeneity. This may seem unconventional as my practice is in the line of supporting whannau and making a change in Aotearoa Society, challenging process and worldviews. The Ministers statement that the declaration is an affirmation of rights only shows me that we have taken on board statements and hegemonic power from the political world.

\section{Indigeneity verse Whakapapa - I have a whakapapa why do you class me as indigenous?}

The contrast between whakapapa and indigeneity may seem quite removed because if I look at the declaration, it does not utilise whakapapa as a primary source of knowledge. To put this into context, I see myself as Ngaitai, Ngāti Porou and Ngāti Raukawa aligning to the teachings and mātauranga of my tipuna.

Remembering that the declaration is universal and the terms indigenous, and indigeneity can also be multi-faceted utilised around the world, at a national level right down to a local level. Austin (2014) in his thesis discusses Hei Tiki: He Whakamārama Hōu and uses the term Indigenous agency, 
Wards (2009:15) states: "Indigenous agency is also evident in the reproduction of material culture for sale to collectors" which can be used as a platform to display the uniqueness of local entrepreneurial trade. However, Austin (2014) makes note that it can also diminish ancestral status.

Toi (2018) discusses the use of the terms Indigenous and indigeneity. Her insight examines Mana Wahine and the space of indigeneity and the complexities in a Governance world. Māori women have to "look at their customs and traditions to articulate theories of self-determination". Toi also makes note that both the terms Indigenous and Māori are not our own but a labelling stemming back to the early 19 century and in a time where colonisation was alive and kicking. This is also the argument from Kuper which I mentioned earlier around the "ideological makeover of the old idea of "primitive people'" (Kuper, 2006). I can only imagine this would have been an interesting robust debate if these terms were discussed today and I believe the positioning of tikanga Māori would have been rocked to its very core with perhaps the reversal of roles between male and female.

The term indigeneity I have found to be hard to trace and to pinpoint and in the Oxford English Dictionary only describes the word as a noun describing it to be "collective rights based on the indigeneity of the community" and in the Collins English Dictionary and the Cambridge English Dictionary it refers back to the word indigenous. The term indigeneity already then poses questions about the reliability and sustainability of the "collective rights of a community" if this term is used.

Cuthers (2018) talks about the reclaiming of identity from his tacit knowledge and whakapapa is key to his discovery of truth "whakapapa allows an individual to locate themselves in the world".(p.375)

Rito (2007) also discusses whakapapa from his background but also incorporates the pūrākau of Papatuanuku which "demonstrates the strong connections between whakapapa and Māori Identity. (p.1)

The reclaiming of identity and the connections that Māori has in all things from creation to daily living are unique in design, on a local level it is complex, it is whakapapa, it is language, it is the pūrākau, whakatauki and waiata to name a few that have moulded our sense of knowledge. These are part of the paradigms Royal (2007) 
discusses the notions of Te Ao Māori to Te Ao Marama while remaining distinctive.

Kuper (2006) also looks at the notion of indigenous peoples and the use of the term from a local perspective where it can be misleading and "not fit a variety of complicated local situations". "Moreover, the messy consequences of imposing these models are drearily predictable. NGO's will identify some people in a region as truly indigenous. Organisations will begin to speak for this category of local people" (Kuper, 2006 as cited in Guenther, 2006).

Whakapapa is a principle and spiritual link to tipuna and historical events through the generations. Moana Jackson (as cited in Bargh, 2007) explains whakapapa as a "history of repetitious beginnings" wherein the "present and future are only the past revisited - ka puta mai - things come into being, is born of something else" (p. 173). Whakapapa is cyclic, not linear, and reflects a view wherein "the universe is not static but is a stream of processes and events" (Marsden, 2003, p.21)

With this said, the argument here is that whakapapa could get lost when there is a utilisation of the term indigeneity. To use and to say that my 'indigeneity' stems from the theories and mātauranga of Te Ao Māori could also confuse the space of kaupapa Māori and things that I have learnt through the generations.

\section{Indigenous Social Work Practice - Indigenous, indigeneity on the front lines}

Within my practice of Social Work, the challenge has been to rename the term Social Work and to look at the actual front-line practice of the practitioner. Indigenous Social Work practice and the terms used is a way to lay the foundations of indigenous knowledge, theories and values. Hollis-English (2015) explains that "enhancing one's knowledge of Te Ao Māori and evidence-based practice, social workers can use, develop and create Māori theories in a social work context for the benefit of Māori whānau and communities".

Much of the social work practice in Aotearoa is underpinned by western knowledge and theories which also influences practices and organisations where Māori social workers often work also where Māori whānau access 
supports. If Māori social workers identify as Māori and work within the realms of Te Ao Māori, they have done so by establishing evidence-based practices that are guided by Te Ao Māori. Here we have a clash of the Taniwha and Titans with both western and Te Ao Māori theories. There is still an imbalance of practice, and in most cases, the voice of Māori is not heard. The challenge should one be daring enough would be to utilise the words 'indigenous' and then see the reaction of their Pakeha colleagues a bit cheeky I know as we should not have to justify our worldviews. Once again this could be seen as the declaration validating our belief systems. (Hotereni, 2018; Hollis-English, 2015)

Russell (2000 p10) explains that "Native Theory is the right of indigenous people to make sense of their time and places in this world" Native Theory was introduced as a research approach to allow Māori researchers to do projects for Māori using knowledge, tools and processes that may not be acceptable from a western perspective (Eketone, 2004)

On a larger scale, the use of the terms indigenous and indigeneity can be used to fulfil the purpose of Social Work Practice. It allows the practitioner to work in culturally appropriate ways with whānau with no pressure from utilising western thinking and ideology.

Within an agency, service provider or organisation who base their practices on Kaupapa Māori theories and then utilising United Nations Declaration of Indigenous Rights as part of their policies, does this enhance and support Māori social workers in practice? Alternatively, is it a justification to work with Māori whānau? If our leaders are willing to use the declaration are they also willing to support Māori Social workers as agents of change? The other argument could be that we Māori social workers need the justification of the terms indigenous and indigeneity to understand the complexity and nature of social work practice. If this is so then the utilisation of whakapapa may not have its unique standing.

When the words Kaupapa Māori and whānau ora are used, in my workplace the realities of practice and knowledge comes from the hegemonic tradition of the white world. In my line of work and a kaupapa Māori organisation, it is crucial for me that my practice stems from the philosophies of Te Ao Māori. According to Smith (1999) "Māori knowledge represents the body of knowledge which 
in today's society, can be extended alongside that of existing Western knowledge" (p. 173).

Eketone (2008) also discusses Kaupapa Maori Theory where Kaupapa Maori Theory challenges and critiques western approaches "Therefore this implies that indigenous, and more specifically Māori approaches cannot exist outside these frameworks and maintain some form of validity" (p. 6)

Wheturangi Walsh-Tapiata (2004) in her keynote speech at the Global Social Work Conference of IASSW and IFSW held in Adelaide expresses the following:

"For Social Workers who work with indigenous populations, it is critically important that they have a correct understanding of the history of that indigenous population and see the impact that history has had on them, much of which is still evident today. Personal troubles cannot be separated from public issues, and social workers need to understand how they have historically contributed to the colonisation process, but also how they can play critical roles as social change agents. Social workers should ask themselves these questions: Are you an agent of control, an agent of compliance or an agent of change? Do you perpetuate oppression or attempt to change it?" (WalshTapiata, 2004)

Within social work practice here in Aotearoa the foundations of Te Ao Māori mātauranga can be linked through the use of pepehā, pūrākau and whakataukī, which establish links to whakapapa that are essential elements of mātauranga for Māori (Marsden, 1979; Ngata, 1985; Moon, 2003; Mead, 2003.) In my view, there is no link for other nations to utilise the uniqueness of our understanding within the space of kaupapa.

The statement towards social workers is also a reminder that historical events have an impact on nations. Weaver (2001) states that the view of a Social Workers is that of a "Child snatcher" it is also a view in many indigenous nations and Aotearoa it is also familiar with Oranga Tamariki. A line must also be drawn where indigenous communities understand and recognise their strengths in their contextual world. (Munford and Walsh-Tapiata, 2001).

Gray et al. (2008) in their view on social work also debates "Indigenization as making social work fit local contexts". They also say, "indigenisation, questions the relevance of Western social works as a professional model of practice with a universal application", "It is part of the 
profession's continuing struggle with diversity, specifically its inability to work effectively with people from non-western cultures."

The argument from Gray et al. (2008) is 'an exclusively ethnocentric form of Indigenous social work would be counterproductive to forms of practice that incorporate knowledge and interventions from other cultures." In saying this Indigenous social work does differ from Western social work however the question is around what is the stance of the profession as a whole. How does the profession of social work within the complexities of social justice work in the space of indigenisation? Alternatively, do we need to firstly look at decolonising the practice to fulfil the inherent gifts located in each unique culture?

\section{Conclusion}

The terms Indigenous and indigeneity have had robust conversations through-out the years. We have writers who are for the rights of indigenous peoples, and the history of the terms are highlighted in the discipline of anthropology with political interpretations. Some writers have also questioned the terms and their use on an international and local scale and have to describe the consequences when they are used in the wrong context.

In my practice, the ideology, epistemology, ontology, whakaaro, comes from Te Ao Māori and what I know within the bounds of my Iwitanga. Sommerville (2010) explains that it can be a "dead-end trying to unpack the multiple uses of the terms Indigenous" and questions when and how did Māori become indigenous? There are more conflicts than solutions, and one could "get on with it", or "forget the past move on with the future". Quite strong statements however when I correlate my practice and Ngaitaitanga I have to be clear when delivering the messages. Historical knowledge is also part of our Ngaitaitanga as this is the beginning of where our learnings have travelled through-out the generations.

Yes, I do agree that the terms Indigenous and indigeneity are multi-faceted and in Social Work Practice and they can be used to validate points of view. However, I am Ngaitai, is the positioning of my practice. Although there are varying degrees of learning, the strength of Ngaitai Iwi is in the whakapapa of our tupuna Torere-nui-a-rua and the 
gifts of mātauranga handed down through the generations. Whakapapa at the fore. 


\section{References}

Altman, J., and Rowse, T. (2005). Indigenous affairs. In Ideas and influence: social science and public policy in Australia.

Austin, D, R. (2014). Hei Tiki: He Whakamārama Hōu. A Thesis submitted to the Victoria University of Wellington in fulfilment of the requirements for the degree of Master of Arts in Māori Studies. Victoria University of Wellington. 2014

Brash, R. (1996). Indigenous peoples and the UN Commission on Human Rights: a case of the immovable object and the irresistible force. Human Rights Quarterly 18:782-813

Cherrington, L. (2003). The use of Māori mythology in clinical settings: Training issues and needs. In L. Nikora, M. Levy, M. Waitoki, B. Masters, N. Te Awekotuku \& R. Etheredge (E.Ds.), Proceedings of the National Māori Graduates of Psychology Symposium, 2002: Making a difference (pp. 117-120). Hamilton, New Zealand: Māori \& Psychology Research Unit, University of Waikato

Cunningham, C. (2000). A framework for addressing Māori knowledge in research, science and technology. Pacific Health Dialog, 7(1),62

Cuthers, W. (2018). Reclaiming Identity. Te Kaharoa, 11(1). https://doi.org/10.24135/tekaharoa.v11i1.219

Durie, M. H. (1998). Whaiora, Maori Health Development. Oxford University Press, Melbourne, 2nd edition.

Durie, M.H. (2000). Te Pae Mahutonga: a model for Māori Health Promotion. Palmerston North, Massy University.

Durie, M. (2005). Ngā Tai Matatū - Tides of Māori Endurance. Oxford University Press, Melbourne.

Eketone, A.D. (2004). Tapuwae: Waka as a vehicle for community actions. A thesis submitted for the degree of Master of Consumer and Applied Sciences at the University of Otago. Dunedin, New Zealand. Thesis (M CApSc), University of Otago, 2005.

Eketone, A. D. (2008). Theoretical underpinnings of Kaupapa Māori directed practice. MAI Review, (1), 1-11

Garcia, B., \& Van Soest, D. (1997). Changing perceptions of diversity and oppression: MSW students discuss the effects of a required course. Journal of Social Work Education, 33 (1), 119-129. 
Grey, M., \& Coates, J. (2008). From Indigenization to Cultural Relevance. In M. Grey, Coates, J. and Yellow Bird, M. (eds), Indigenous Social Work around the World: Towards Culturally Relevant Education and Practice. Aldershot: Ashgate, 13-29

Gray, M., \& Hetherington, T. (2013). Indigenization, indigenous social work and decolonisation: Mapping the theoretical terrain. Decolonizing Social Work. 25.41

Guenther, M. (2006). The concept of Indigeneity: Discussion. Social Anthropology. European Association of Social Anthropologists. DOI:10.1017/S0964028205001849

Hollis, A. N. R. (2006). Pūao-te-Ata-tū and Māori social work methods. A Thesis submitted for the degree of Master of Arts at the University of Otago, Dunedin, New Zealand. Thesis (MA), University of Otago, 2006.

Hollis-English, A. (2015). Theories in Māori social work: Indigenous approaches to working with and for indigenous people. Aotearoa New Zealand Social Work issue 27(4), 2015

Hotereni, V. (2018). A Worldview of social work in contemporary society: My tacit knowledge of social work practice. Te Kaharoa: The ejournal on Indigenous Pacific Issues, $11 \quad(1), \quad 413-429$ https://www.tekaharoa.com/index.php/tekaharoa/ar ticle/view/223

Kuper, A. (2003). 'The return of the native', Current Anthropology 44:389-402. 1993. 'Postmodernism, Cambridge and the great Kalahari debate', Social Anthropology, 1, 57-71.

Mead, H. M. ((2003). Tikanga Māori. Living by Māori values. Wellington: Huia Publishers.

Merlan, F. C. (1998). Caging the rainbow: places, politics, and Aborigines in a north Australian town. Honolulu: University of Hawai'i

Merlan, R. C. (2009). Indigeneity. Global and Local. Current Anthropology. Volume 50, Number 3, 2009. DOI:10.1086/597667.

https://www.journals.uchicago.edu/t-and-c

Moon, P. (2003). Tohunga: Hohepa Kereopa. Auckland: David Ling.

Murray, V. (2016). Hoki ki tōu maunga kia purea ai e koe ki ngä hau o Tāwhirimātea - a supervision model. Aotearoa 
New Zealand Social Work, 24(3-4), 3. https://doi.org/10.11157/anzswj-vol24iss3-4id102

Ngata, A. T. (1985). Ngā Moteatea. Wellington: A. H. \& A. W. Reed.

Pohatu, T.W. (2004). Ata: Growing Respectful Relationships: He Pukenga Korero Journal (2004)

Pohatu, T. (2004). Maori Worldviews: Source of Innovative Social Work Choices, Te Wananga o Aotearoa, Manukau

Pohatu, T., \& Pohatu. T. (2006) Mauri - Rethinking Human Well-being. Te Wananga o Aotearoa.

Royal, C. (2007). The Creative Potential Paradigm emerging in iwi/Maori communities. Keynote address delivered to Transform: Te Tinihanga, A Conference of the Library and Information Association of New Zealand, Rotorua 10 September 2007

Russell, K. J. (2000). Landscape: Perceptions of Kai Tahu. Thesis submitted for the degree of Doctor of Philosophy in Anthropology at the University of Otago. Dunedin.

Ruwhiu, L. (1999). Maori social wellbeing in supervision and placements. An unpublished paper

Ruwhiu, L. (2004). Cultural Supervision: A Journey within to strengthen without - a whānau tautoko mahi experience. Paper presented at the Supervision Conference - Weaving together the strands of supervision. The University of Auckland.

Sumervill, A. (2010). Maori Cowboys, Maori Indians. American Quarterly, Vol. 62 (3). Indigeneity, Globalism, and American Studies. Pp. 633-685

Te Rito, J.S. (2007). Whakapapa: A framework for understanding identity. MAI Review, LW,1,(3),10,2007

Tuhiwai Smith, L. (2005). On Tricky Ground - Researching the Native in the Age of Uncertainty. In Denzin, N.K \& Lincoln, Y.s (Eds) Sage Handbook of Qualitative Research (3rd Ed). USA: Sage

Tuhiwai Smith, L. (2007). The native and the neoliberal down under: neoliberalism and

"endangered authenticities," In Indigenous experience today. M. de la Cadena and O. Starn, eds. Pp. 333-352. Oxford: Berg.

Walsh-Tapiata, W. (2004). The past the present and the future: The New Zealand indigenous experience of Social Work. Keynote address delivered to the Global Social Work 
Conference of IASSW and IFSW held in Adelaide, October 2004. 